Meta

Journal des traducteurs

Translators' Journal

\title{
"Better a Live Sparrow than a Stuffed Eagle": Towards a Translation of Guillaume de Machaut's "Dit de l'Alerion"
}

\section{Brenda Thaon}

Volume 23, numéro 1, mars 1978

La traduction poétique

URI : https://id.erudit.org/iderudit/004469ar

DOI : https://doi.org/10.7202/004469ar

Aller au sommaire du numéro

Éditeur(s)

Les Presses de l'Université de Montréal

ISSN

0026-0452 (imprimé)

1492-1421 (numérique)

Découvrir la revue

Citer cet article

Thaon, B. (1978). "Better a Live Sparrow than a Stuffed Eagle": Towards a Translation of Guillaume de Machaut's "Dit de l'Alerion". Meta, 23(1), 37-46. https://doi.org/10.7202/004469ar d'utilisation que vous pouvez consulter en ligne. 


\section{"Better a live Sparrow than a stuffed Eaglen: Towards a Translation of Guillaume de Machaut's "Dit de l'Alerion"}

Surprising though it may be, it was not Guillaume de Machaut's bird allegory, the Dit de l'Alerion, written between 1342 and 1349 that provided the quotation contained in the title of this article, but rather a letter written some five hundred years later by Edward Fitzgerald, the Victorian translator of Omar Khayyám ${ }^{1}$. Fitzgerald's avian metaphors are, however, peculiarly appropriate in more than one way. He uses them to describe his translation of the Persian bird-epic, Mantic uttair, which he entitles Bird Parliament. (Chaucer's Parliament of Fowls, most certainly indebted in some measure to Machaut's Alerion, springs to mind.) It is, he maintains, a «living 》 translation, a « live Sparrow, 》 as opposed to a « literal » one, a «stuffed Eagle. » In making this distinction, Fitzgerald was adding his voice to the age-old chorus of translators who, from Cicero and Horace on, had sung the praises of "rhetorical 》 translation, which rendered the sense of the original, while at the same time condemning the "literal 》 translation of the fidus interpres, which rendered only the words. Machaut, whom Deschamps called \& ce grand translateur, » would also most certainly have opted for the «Sparrow», since in his Confort d'Ami (1357), he offers a translation of some excerpts from the Book of Daniel which, despite his claims that «Dou latin ou je l'ay veu / L'ay mis si pres com j'ay peu », is in parts extremely free ${ }^{2}$. In what constitutes an adaptation rather than a translation, Machaut is going well beyond even the limits set down by St. Jerome, an ardent defender of free translation of all but the Scriptures, whose very sacredness forbad poetic, or any other, licence.

The debate concerning free and literal translation, thrown open by Cicero and Horace and carried on in the post-classical period by St. Jerome and his opponents Boethius and Duns Scotus, was to continue long after Machaut wrote his Confort d'Ami, a fact to which Ftizgerald's remark testifies. Translations progressed from the clumsy and literal, if often inaccurate, offerings of the Middle Ages through the increasingly paraphrastic works of the Renaissance to

1. Edward Fitzgerald, The Variorum and Definitive Edition of the Poetical and Prose Writings of Edward Fitzgerald, ed., George Bentham, 7 vols. (London, 1902, repr. New York, 1967), I, xxxii-iii.

2. Euvres de Guillaume de Machaut, ed., Ernest Hoepfiner, 3 vols. (Paris, 1908, 1911, 1921), MI, iii. Subsequent references to Machaut's poetry, together with the text of the Prologue to the Dit de l'Alerion, will be from this edition. 
the «belles infidèles» of the eighteenth century, whose aesthetic qualities, while commendable, were often not those of their originals. It was not until well into the nineteenth century that translators sought to bring together verbal accuracy and poetic language, to convey literature in terms of literature while at the same time respecting the meaning of the original text. Since then, they have increasingly been expected to steer their course between the Scylla and Charybdis of literality and infidelity. The perils of such a course are many.

It goes without saying that the first step in achieving verbal accuracy is to understand fully and clearly the meaning of the words of the original. This is a problem for any translator, but it is a particularly difficult one for the translator of poetry who, in transposing a poem from one language to another, becomes at the same time its interpreter. Once he has grasped and interpreted the meaning of the source text, he has to select those words in the target language which will best convey both the original's meaning and its tone. Again, this challenges the poetic translator in a very special way, for he must express himself in language which will detract as little as possible from the poetic design and effect of the original while at the same time communicating as fully as possible its meaning. He must, therefore, strive to produce poetic imagery (as well as devices like puns, internal rhyme or alliteration if, indeed, such devices are part of the poet's style) in his own language, exploiting his own linguistic resources. This, then, is the gauntlet cast before the translator of poetry who, more than any other, is brought, as George Steiner says «face to face, as by no other exercise, with the genius, bone-structure and limitations of his native tongue ${ }^{3} \gg$.

Closely allied to the question of poetic language is that of poetic form. The debate concerning the comparative merits of verse and prose translation has, in terms of fervour and endurance, equalled if not surpassed that which opposed literal to free translation. Arguments in favour of verse translation have for the most part been posited by translators who were first and foremost poets, sceking in their translations to create «new » poems from old. Yet a verse translation, however «poetic» in its own right, often preserves the outward form of the original at the expense of its meaning; rhythm and rhyme can prove hard taskmasters, as Marie Borroff acknowledges in the introduction to her remarkable verse translation of the alliterative Gawain and the Green Knight ${ }^{4}$. Those who defend metrical translation on the grounds that poetry can only be translated faithfully by poetry are surely deluding themselves. A verse translation can no more be faithful to, or the same as, the original poem than can a prose paraphrase, for language, time and context have changed. To quote Dorothy Sayers' description of her translation of The Divine Comedy, « it is not, of course, Dante; no translation could ever be Dante ${ }^{5} \gg$. The same is true of any poet worthy of the name.

3. George Steiner, ed., The Penguin Book of Modern Verse Translation (Harmondsworth, Middlesex, 1968, p. 27.

4. Sir Gawain and the Green Knight, trans., Marie Borroff (New York, 1967), p. xiii.

5. Dante Alighieri, The Divine Comedy, 3 vols., trans., Dorothy L. Sayers (Harmondsworth, Middlesex, 1949), I, 55-56. 
As for prose translation, it can more faithfully render the sense of the original poem, more successfully maintain its structure and achieve greater verbal accuracy than its metrical counterpart whose elegance, at least, it can sometimes rival. It cannot, however, do full justice to the original for the simple reason that poetry and prose are different media, demanding different language and syntax, using different modes in which to express meaning, and moving in different rhythms. The prose translator can, of course, add «poetic » touches to his prose (alliteration, internal rhymes, et cetera) but with caution. Otherwise, he will have produced a hybrid, "unfaithful " to the source and belonging to neither the world of poetry nor prose.

Where, then, does this leave the would-be translator of medieval poetry, who encounters not only these problems but also several others of a more specifically scholarly nature? Is he to concede, however ruefully, that Dante and Du Bel'ay were right, that poetry's «dolcezza e armonia " and «divinité d'invention $\gg$ are best left untouched by the translator's pen? To do so, however, would be to deny many the pleasure of reading poetry which is often part and parcel of their national as well as their cultural heritage. How many non-specialist readers can understand the English of Chaucer, or Gawain, or the Harley lyrics ? How many modern French readers can understand Chrétien de Troyes? The translator of old texts therefore plays an important role in breaking down not only the barriers of culture and language but also of time. It was upon such an argument that Dryden based the defence of his translation of Chaucer. Conceding that \& something must be lost in all... Translations», he nevertheless goes on to say that «the Sense will remain, which would otherwise be lost, or at least maim'd, when it is scarce intelligible ; and that but to a few ${ }^{6} \gg$.

We mentioned the difficulty encountered by the poetic translator in interpreting his source text. In the case of medieval poetry, this difficulty is often compounded by the fact that the reliability of the actual text itself can be called into question. The translator is, in such circumstances, required to play the additional role of editor, referring back to original manuscripts or to facsimiles where no critical edition exists. A point well worth mentioning, too, is that manuscripts of medieval poetry very rarely contain any forms of punctuation. In the absence of a reliable editor, the translator has to decide how to punctuate the text himself.

Another particular difficulty is that many of the words used by the medieval poet have become obsolete while the original meanings of those that have survived have often been obscured by time. Again, Dryden's comments are appropriate : «If the first End of a Writer is to be understood, then as his Language grows obsolete, his Thoughts must grow obscure», for, he continues, quoting Horace's Art of Poetry (which also gave us the term fidus interpres), words live and die only to be born again if usage so wills it ${ }^{?}$. The translator, Dryden

6. John Dryden, Preface to his a Fables Ancient and Modern $\gg$, in : The Poems of John Dryden, ed., James Kinsley, 4 vols. (London, 1958), I, 1458.

7. Loc cit., multa renascentur qua iam cecidere, cadentque qua nunc sunt in honore vocabula, si volet usus, quem penes arbitrium est et ius et norma loquendi. 
maintains, is an instrument by which many of these archaic terms can be revived. If he wishes to evoke the true meaning and tone of the original, the translator can, if translating from an old to a modern form of the same language, choose words which are etymologically close to those of the original yet, it goes without saying, familiar enough to be understood by the modern reader ${ }^{8}$. A word of caution is needed here, however. The translator must avoid using archaic clichés of the type indulged in by many of the English Romantic and Victorian poets in their attempt to achieve an authentic «flavour» of the Middle Ages. When translating an old text from a foreign language, the attempt to preserve archaisms becomes all the more difficult and meaning is often abandoned for tone and \& atmosphere ». In fact, some translators have defied the very purpose of translation itself by employing such a wealth of unfamiliar archaic diction in the target language - again done in order to preserve the "flavour 》 of the originals - that their versions are equally if not more obscure ${ }^{9}$.

Some of the problems, if not all, that we have outlined apply to translating Machaut's poetry. From the textual point of view, the translator is indeed fortunate. Machaut's poems were collected together and published in manuscript form during the poet's lifetime, probably under his supervision, a rare occurrence in the Middle Ages ${ }^{10}$. The whole body of lyric poetry was carefully edited by Chichmaref in 1913 and much of it has since been anthologized by different editors. A large part of the narrative poetry, including the Dit de l'Alerion, appears in the scholarly Hoepffner edition published by the Société des anciens textes français. From the linguistic point of view, however, it can be said that Machaut's poetry, despite good editing, offers quite a challenge. The poet stands, philologically speaking, between two worlds, the Middle Ages and the Renaissance, occupying a middle ground that has been relatively neglected by historians of the language. The period covered by most Old French grammars and philological studies opens at 1100 to close again at 1300 , two centuries before Du Bellay's Défence et illustration de la langue française. Old French dictionaries and glossaries are useful but share the limitations of their modern counterparts.

Nor could the translator have found, at least until recently, much elucidation in the pages of literary history, for Machaut has fared little better at the hands of critics than at those of philologists. They have traditionally coldshouldered the XIvth century, looking backward to the glories of Chrétien, the troubadours and the Roman de la rose and forward to the poetry of the Pléiade. This situation has been rectified over the past few years, particularly with

8. The translator is also able to preserve forms of archaic syntax, as André Mary has done in his translation into modern French of Chrétien de Troyes' Yvain. Julian Harris, in his forward to the translation, points to the a ellipsis of the subject pronoun... the inversion of verb and subject; the omission * pas * in negative statement * that evokes some of the "flavour " of the original. Chrétien de Troyes, Yvain, ou le Chevalier au Lion, trans., André Mary (New York, 1963), p. 11.

9. It is unlikely, for example, that Emile Legouis' rendering of Edmund Spenser's Faerie Queene into Sixteenth-century French will have increased that poet's readership in France.

10. Sarah Jane Williams, "An Author's Role in Fourteenth Century Book Production : Guillaume de Machaut's a Livre ou je met toutes mes choses », Romania 90 (1969), 433-454. 
regard to Machaut's narrative verse, which had hitherto received but passing interest, in France for its influence on later French narrative poets and in England for its influence on Chaucer ${ }^{11}$. Recent critics of English literature have strengthened the case for Chaucer's indebtedness to Machaut in his Book of the Duchess, House of Fame, Legend of Good Women, and Troilus and Criseyde. One, in particular, has suggested that Machaut's influence is far more pervasive than has hitherto been believed ${ }^{12}$. In actual fact, many of the " echoes 》 of Machaut's dits amoreux are either direct translations or adaptations. As for the Dit de l'Alerion, its links with the Parliament of Fowls, first pointed out by Edith Rickert in 1920 , are now widely recognized by critics ${ }^{13}$. Moreover, Constance B. Hieatt, recently arguing for a new and more favourable appraisal of the poem, has suggested further links between Alerion and Chaucer's Squire's Tale, Nun's Priest's Tale and, possibly, Franklin's Tale ${ }^{14}$.

In view of the increasing importance being given to Machaut's narrative verse and its place in the history of French medieval poetry, and in view of a renewal of interest in the question of the poet's influence on Chaucer, the time is perhaps ripe to make his longer poems accessible in translation to those English readers for whom medieval French is a stumbling block. The present article has sought to describe, in what might be called a clearing away of the trees, some of the problems that such a translation could pose. What in fact will emerge, forest or more trees, can perhaps be judged from the following translation of the opening lines of the Prologue to the Dit de l'Alerion and the commentary that accompanies it. The Prologue was chosen not for any lyric flights, which are in fact noticeably absent from both Prologue and poem, but for its examples of wordplay, to which it is always difficult to do justice in a translation.

The Dit de l'Alerion, one of Machaut's longest and most didactic love narratives, appears in one manuscript as the Dit des quatre oiseaus, after the poet's own description of his poem in its final line. And it is, in fact, the story of four birds. The narrator, a lover of falconry, tells how he trained a hawk, an allerion, an eagle and a gerfalcon but was abandoned by all four. Seeking consolation in Nature, however, he was reunited with the allerion, his favourite. The poem is, of course, more than a simple tale of falconry. It is a love allegory using falconry as its vehicle; the four birds are symbolic representations of the narrator's four mistresses and the lessons they teach are those learnt by the narrator in the courts of love. The poem is an ars amandi in the tradition of Ovid and the Roman de la rose, teaching the reader how to love, how to be-

11. William Calin, A Poet at the Fountain. Essays on the Narrative Verse of Guillaume de Machaut (Lexington, Kentucky, 1974).

12. James Wimsatt, Chaucer and the French Love Poets (Chapel Hill, North Carolina, 1.968).

13. Edith Rickert, A New Interpretation of the * Parliament of Foules *, Modern Philology, XVIII (1920-1921), 1-29.

14. Constance B. Hieatt, *Une autre fourme : Guillaume de Machaut and the Dream Vision Form ", paper delivered at the Medieval Academy of America Meeting, Toronto, 1977. 
have with his lady and what to expect of her, and how to console himself when abandoned.

The Prologue serves as an introduction to the poem in several ways. It suggests that there are four means by which to do well in the world, as indeed there are four ways to experience love, through kind thoughts, kind words and kind deeds, and through the rejection of unkindness. The four are symbolized by the four birds. Similarly, there are three stages in men's lives as there are three stages in a love affair, the initial conquest, followed by a time in which love flourishes, and ending in separation and the lover's need for consolation. Lastly, the Prologue states, a man will have already displayed his tastes and tendencies as a child. The poet-narrator of the falconry romance is the young bird lover of the Prologue; on the allegorical level, the man experienced in love will have shown all the signs and symptoms of fin' amor when young. The exploration of the first two ideas is contained in the first forty-eight lines of the Prologue, as follows :

\section{Le Dit de l'Alerion}

En tout le monde entierement, Pour vivre seculerement,

N'a seulement que .IIII. poins ;

Et il est adès temps et poins

De ces .IIII. poins maintenir,

Qui vuet droite sa main tenir;

Et qui a droit en useroit

Plus justement en viveroit.

Il sont a nommer moult legier,

Mais ils sont fort a esligier.

Nompourquant qui les aimeroit

Legierement en useroit.

Bien penser, bien dire, bien faire

Et eschuer tout le contraire,

Cils .IIII. poins, je n'en doubt mie,

Attraient toute bonne vie.

Or dit en une autre fourme

De quoi ma pensée s'enfourme,

Que chascune chose a .III. temps,

Dont s'aucuns puet venir a temps

Au premier, cils temps li enseingne

Le secont; lors voit il l'ensengne

Dou tiers temps, selonc la besongne

Qui parmi trois temps l'embesongne.

Des .III. dis prouverai je fin

Commencement, moien et fin.

De ces .III. se doit enfourmer

Qui bon ouvrage vuet fourmer.

Et s'aucuns pense mauvaisté,

Gart bien, selonc la vérité,

Que commencemens ne li tart;

Car il n'i puet venir trop tart.

Mais qui vuet bonne ouevre avancier,

Trop tost ne puet encommancier, 
Pour ce que temps adès s'en court.

Et qui fait ouvrage trop court,

Je ne puis veoir ne penser

Qu'on li doie recompenser,

Que selonc l'uevre le salaire.

Je ne doubt mie le contraire.

Mais qui commence temprement

Et il a bon commancement,

Mais qu'il ne rompe le loien,

Ill doit venir a bon moien.

Et quant au moien est venus,

De bien en mieus bons devenus,

Envis puet estre qu'il ne traie

Dou tiers temps trés souffissant paie.

The Story of the Allerion

In the whole world, from end to end,

If in the world a man would live,

There are but four points he should heed-

They're always meet and to the point-

JFour points to honour as a right

If he would steer his course aright.

For if of them he makes right use,

Then he will lead an upright life.

To preach them is an easy task,

To practise they're more difficult.

Yet if he loves them well enough,

With ease he'll put them to good use.

'To think, to say, and do no ill,

And shun all to the contrary.

l've not a doubt that these four points

Must bring about a proper life.

To express this in a different form,

One of which I'm well informed,

All things move through three fixed times.

Now if the first you start bedtimes,

It to the second soon will sign.

Then you can't but mark the sign

Of the third; throughout all your labour

Three times o'er you'll be belaboured.

They're cal'ed, I'll prove it in the end,

Beginning, middle and the end.

You must of all three be informed

If you your task would right perform.

If someone have a ruse in mind,

He'd best take care, for verily,

He must start off without delay,

He'll ne'er start out if he delay.

But those who'd proceed as they should

Cannot begin their work too soon;

Time's always coursing on its way.

To cut short your work's natural course

Will reap, as far as I'm concerned, 
Only the reward it deserves;

One's only paid for work that's done.

I can't conceive it otherwise.

But he who makes a timely start

And starts out in the proper way

Will, if his passage remain smooth,

Safely attain the middle stage.

And when the middle he has reached,

Having progressed from strength to strength,

No doubt at all but that he'll gain

Ample share of the third time's meed.

In the introductory part of this article, we spoke of the choice of form - poetry or prose - that faced the poetic translator. It was suggested that prose translation was better able to achieve verbal accuracy, since the constraints of rhythm and rhyme often resulted in too free a translation. By way of reply to accusations that the present translator has flown in the face of her own advice two points may be made. The translation was subjected to only the first of these constraints. Octosyllabic lines seemed manageable: rhyming couplets, it was felt, were best left to Pope ${ }^{15}$. Secondly, the Prologue to the Dit de l'Alerion is not, as we have already pointed out, lyric poetry; it is a didactic introduction to an almost equally didactic poem. It was therefore easier to adhere to the dictates of rhythm while remaining faithful to the meaning and tone than in some of Machaut's other, more lyrical narrative verse. The challenge lay in its wordplay and rhetoric, as will be seen in the following commentary.

The first question of particular interest in terms of translation is raised by the title of the poem. A dit, which was a specific literary genre in the Middle Ages, is a story or a tale about a familiar subject of general interest. The more popular ones were the dits amoreux, or tales of love, of which Alerion is one. The English words «tale» and «story» are acceptable as a translation; both stretch back to the Middle Ages, both convey the exact meaning of dit. "Tale 》 would have been the more suitable because it evokes Chaucer's great poem, but context forbids it. Translated as « The Tale of the Allerion », the title would have left the reader wondering whether the translator were trying to out-pun the poet. As for the word «alerion» itself, it has been translated by English critics as "eaglet ", which it is not, "small eagle», which it probably is, or has been left in its French form and underlined as a foreign term. "Small eagle 》 is not suitable for a title on stylistic grounds; « eagle», which might have well served in another context, cannot be used here because the third bird that the narrator acquires is an actual eagle (aigle). Considering the confusion concerning the exact nature of the bird, that reigned while Machaut himself was writing (the Latin bestiaries and treatises claimed it was a bird of prey bigger than the eagle while Machaut says it is «de taille pas moult grand》 and other medieval writers describe it as a small eagle without claws or beak) ${ }^{16}$, the safest and

15. Or, of course, to Chaucer, whose Book of the Duchess and Legend of Good Women are both written in rhyming couplets, as is The Romaunt of the Rose, a translation of the French poem in which Chaucer is believed to have had a hand.

16. Hoepffner, op. cit., III, lxviii. 
perhaps most accurate translation is "alerion», or in its variant spelling, « allerion».

The commentary that follows addresses itself to those lines which were difficult to translate or which were of particular interest. The Prologue opens with a wordplay on «monde》 et «seculerement 》 which it is impossible to render fully in English because the adverb «secularly 》 has now lost its broader meaning (according to the O.E.D. it means « ecclesiastically » or « in a manner characterized by an absence of religion $\gg)$ and «worldly » carries with it a negative connotation which is missing from the Old French « seculerement $\$$. The four rules by which a man must be governed, if he would lead a decent life in this world, are called "poins». The word provides Machaut with yet another opportunity for wordplay. It is always « temps et poins $»$ - the right time and place - to remember these four "poins», or important points (11. 4-5). The wordplay can be kept in English with the phrase «to the point », although it is not the exact meaning of «poins 》 nor does it constitute a true pun as does the French. Machaut then moves on to a visual pun in lines 5-6 : «maintenir», meaning \& to keep to , and « main tenir», in a phrase which he created and which presumably means \& to keep on the right course ». The visual pun is kept in the English but again at the expense of the exact meaning of \& maintenir ». The idiom, too, it goes without saying, has to be changed. The poet's play on «droite», «a droit», meaning « avec raison» or « justement», leads in to the «justement of line 8 and is maintained in the English by the words « aright», « right use », and « upright». In lines 9 and 12, Machaut indulges in one of his favourite devices, repetition of a word but as a different part of speech, here «legier» and « legierement», translated by « easy » and "with ease $\%$.

This section of the Prologue ends with an internal rhyme, «doubt» and 《toute» (11. 15-16), echoed by the English «doubt» and «about» and with the confident statement that these four points - to think, to say, to do no ill, and to eschew the contrary - «attraient toute bonne vie ». One critic's translation of this is that the four points will tell us how to lead «the good life ». This, surely, is wrong because the phrase carries with it an idea of material success - " the good life » has become a synonym for «the high life »which is contradicted by the very moral nature of the advice.

The etymological wordplay in which Machaut delights comes into its own in the second section of the Prologue. «Fourme » and \& s'enfourme » are kept in «form》 and « informed » (11. 17-18) but later on become "perform》 and $s$ informed $»(11.27-28)$ because work, tasks, duties, jobs, et cetera, cannot be «formed \& in English. A similar wordplay is found in «besongne », meaning * task» or "occupation », and «embesongne », meaning « to occupy », rendered by «labour » and «belaboured».

Other wordplay is found in «temps $\gg$ and « a temps»(11. 19-20) translated by «times» and «betimes», meaning « on time» or «timely», a word taken up again in line 41 to translate the adverb «temprement» and in « fin », meaning «enfin», and «fin», meaning «conclusion». The English keeps the 
repetition and the meaning with « in the end $»$ and «the end $»$. The only true pun is to be found in «s'en court» and «court», for which it seems impossible to find a translation since no one English word will convey the meaning of «s'en courir» and «court». We have suggested a repetition of " coursing 》 and "course », which is certainly in the spirit of Machaut if not in the letter, and have translated "court » by to «cut short». Thus although the pun is lost the tone is not. A similar interplay of noun and verb appears, in fact, in Machaut's "enseingne 》 and «l'ensengne 》 and in the translation of the two words (11. 21-22).

Certain other attempts have been made to preserve the «spirit» of Machaut. Earlier in the article it was suggested that the translator of medieval poetry could use archaic diction if he were able to make its meaning clear and avoid clichés. Hopefully, the few archaisms which appear in this translation will have satisfied both conditions. Three out of the five were chosen not only for their archaic quality but also because they made it possible to translate the wordplay found in the original : «betimes», «belaboured», and «timely». The adverb "verily and the noun «meed» were chosen for purely stylistic reasons; they should, however, be familiar to more than just the readers of the King James Bible and Piers Plowman.

As was pointed out previously, this short piece of translation is intended as an exploratory exercise, carried out with a view to making Machaut's narrative poetry accessible to those English readers who do not know Old French. We made fidelity to the original our first concern but not, we trust, to the complete exclusion of what Fitzgerald called \& liveliness ", for while on the one hand we do not presume to call our translation, as did Machaut his allerion, a «parfait oisel », we do, on the other, hope that it will not be assigned a place among Fitzgerald's «stuffed eagles ».

BRENDA ThaON 